\title{
Effects of cytochalasin $B$, colchicine, and vinblastine on progesterone synthesis and secretion by bovine luteal tissue in vitro
}

\author{
Anne Gwynne and W. A. Condon \\ Department of Animal Sciences, The University of New Hampshire, Durham, \\ New Hampshire 03824, U.S.A.
}

\begin{abstract}
Summary. Exposure of bovine luteal tissue to the anti-microfilament agent cytochalasin B inhibited both basal and $\mathrm{LH}$-induced steroidogenesis, but had no effect on the portion of the progesterone secreted into the incubation medium. Addition of $10 \%$ calf serum to the incubation medium caused no significant increase in progesterone synthesis, but produced a significant increase in the portion of the progesterone found in the incubation medium. This increased secretion in the serum-containing medium was not altered by the presence of $\mathrm{LH}$, and cytochalasin $\mathrm{B}$ was unable to prevent it. Exposure of the luteal tissue to the antimicrotubular drugs, colchicine and vinblastine, produced no alteration in synthesis or secretion of progesterone, even when LH was present, and neither drug inhibited the serum-induced increase in secretion of progesterone. These studies suggest that luteal cell microfilaments may be involved in LH-stimulated progesterone production while microtubules apparently play no direct role in progesterone synthesis.
\end{abstract}

\section{Introduction}

The cellular events involved in the gonadotrophin-induced synthesis of progesterone by the corpus luteum (CL) from the binding of the gonadotrophin on the plasma membrane through the conversion of pregnenolone to progesterone in the smooth endoplasmic reticulum have been extensively examined (Christensen \& Gillim, 1969; Savard, 1973; Catt \& Dufau, 1976; Marsh, 1976). The processes of transporting the newly synthesized progesterone to the cell periphery and its subsequent extracellular discharge have received far less attention. Recent studies suggest that after synthesis in the smooth endoplasmic reticulum, progesterone is packaged into secretory granules (Gemmell, Stacy \& Thorburn, 1974; Quirk, Willcox, Parry \& Thorburn, 1979; Parry, Willcox \& Thorburn, 1980). This packaging process may include a progesteronebinding protein, and most probably occurs in the Golgi apparatus of the luteal cell (Sawyer, Abel, McClellan, Schmitz \& Niswender, 1979). The mechanisms involved in the transport of these secretory granules from the Golgi apparatus to the luteal cell membrane are not known. It has been suggested, however, that components of the cytoskeleton, particularly microtubules and microfilaments, may be involved in the transport of secretory granules (Lacy, 1975; Bassett \& Pollard, 1980; Means \& Dedman, 1980). Microtubules are present in luteal tissue (Gemmell \& Stacy, 1977), and colchicine, a pharmacological agent that disrupts the microtubular system by causing depolymerization of tubulin, interferes with the secretion of progesterone from the 
ovine CL (Gemmell \& Stacy, 1977; Sawyer et al., 1979), but not from rat luteal cells (Azhar \& Menon, 1981). However, exposure of luteal tissue to the antimicrofilament agent, cytochalasin B, suppresses gonadotrophin-induced progesterone production in sheep (Silavin, Moss \& Niswender, 1980) and rat (Azhar \& Menon, 1981) luteal tissue in vitro.

The present study was undertaken to determine the role of microtubules and microfilaments in progesterone production in bovine luteal tissue slices in vitro, and in the subsequent secretion of progesterone into the incubation medium.

\section{Materials and Methods}

Corpora lutea were removed per vaginam from regularly cyclic, non-lactating dairy cows of various breeds during the mid-luteal phase (Days 8-12) of the cycle. The tissue was quartered, sliced, washed, weighed, and incubated in $25 \mathrm{ml}$ Erlenmeyer flasks containing a final volume of 5 ml Ham's F-10 culture medium (Microbiological Associates, Bethesda, Maryland, U.S.A.) with 24 mM-Hepes buffer (pH 7.4) (Calbiochem-Behring Corp., La Jolla California, U.S.A.) (Condon \& Black, 1976). Each flask received 4 slices, one from each quarter of the CL. The tissue weight per flask was $150-200 \mathrm{mg}$. A portion of each CL was immediately frozen for subsequent determination of the amount of progesterone present in the luteal tissue before incubation. The tissue was incubated at $37^{\circ} \mathrm{C}$ in a Dubnoff metabolic shaking incubator for $2 \mathrm{~h}$ with air as the gas phase. Duplicate determinations of all treatments were performed for each CL.

The various compounds added to the incubation medium as indicated were: bovine luteinizing hormone (NIH-LH-B9), colchicine and vinblastine sulphate (Sigma Chemical Co., St Louis, Missouri, U.S.A.), cytochalasin B (Aldrich Chemical Co., Milwaukee, Wisconsin, U.S.A.), and calf serum (Grand Island Biological Co., Grand Island, New York, U.S.A.). The colchicine, vinblastine and cytochalasin B were always added $30 \mathrm{~min}$ before the addition of LH. All treatment additives were dissolved in the culture medium except the cytochalasin B, which was solubilized in dimethylsulphoxide $(0.2 \%, \mathrm{v} / \mathrm{v}$, final concentration), and all substances were added to the incubation flasks in $0.1 \mathrm{ml}$ aliquots.

After incubation for $2 \mathrm{~h}$, the tissue slices were separated from the incubation medium and frozen immediately in a solid $\mathrm{CO}_{2}$-acetone bath. Upon thawing, the tissue slices were homogenized in $1 \%(\mathrm{w} / \mathrm{v}) \mathrm{NaOH}$, and both the homogenate and the incubation medium were extracted with $10 \mathrm{ml}$ petroleum ether (b.p. $35-60^{\circ} \mathrm{C}$ ).

Progesterone was measured by a radioimmunoassay with an anti-progesterone-11-BSA serum (GDN-337) donated by Dr G. D. Niswender. This antiserum does not cross-react significantly with any abundant steroid in our samples (Gibori, Antczak \& Rothchild, 1977). The quantity of progesterone contained in the tissue plus the amount found in the incubation medium (i.e. total progesterone in the flask) was collectively referred to as progesterone synthesis or production, and was expressed as $\mu \mathrm{g} / \mathrm{g} / 2 \mathrm{~h}$. The progesterone found in the incubation medium alone represents secretion, and was expressed as a percentage of that synthesized (i.e. a percentage of the total).

The intra-assay coefficient of variation was $9.8 \%$; the inter-assay coefficient of variation was $15.6 \%$. The limit of sensitivity of the assay was $0.1 \mathrm{ng} / \mathrm{ml}$. All standards were assayed in quadruplicate, and all unknowns were assayed in duplicate for 2 different aliquots. Differences in progesterone levels between groups were assessed by Student's $t$ test.

\section{Results}

Addition of $\mathrm{LH}(1 \mu \mathrm{g} / \mathrm{ml})$ to the incubation medium significantly increased progesterone synthesis, but had no effect on the fraction of the progesterone that was secreted into the 
incubation medium (Table 1). Calf serum produced no significant increase in progesterone synthesis, but there was a significant increase in the portion of the progesterone secreted into the incubation medium (Table 1).

Table 1. Effect of LH and calf serum on progesterone synthesis and secretion by bovine luteal tissue in vitro

\begin{tabular}{lcc}
\hline $\begin{array}{c}\text { Addition to } \\
\text { medium }\end{array}$ & $\begin{array}{c}\text { Progesterone synthesis } \\
(\mu \mathrm{g} / \mathrm{g} / 2 \mathrm{~h})\end{array}$ & $\begin{array}{c}\text { Fraction secreted into } \\
\text { incubation medium (\%) }\end{array}$ \\
\hline None & $77 \cdot 7 \pm 9 \cdot 5$ & $34 \cdot 2 \pm 1 \cdot 5$ \\
$\mathrm{LH}(1 \mu \mathrm{g} / \mathrm{ml})$ & $128 \cdot 8 \pm 7.9^{*}$ & $32.4 \pm 1 \cdot 8$ \\
Calf serum $(10 \%)$ & $90.3 \pm 11.0$ & $54.4 \pm 2 \cdot 4^{* *}$ \\
\hline
\end{tabular}

Values are mean \pm s.e.m.

Compared with control value; ${ }^{*} P<0.01(n=7) ;{ }^{* *} P<0.001(n=5)$.

Addition of cytochalasin B inhibited both the basal and the gonadotrophin-induced synthesis of progesterone (Table 2). Dimethylsulphoxide, in which the cytochalasin B was dissolved (final concentration of $0.2 \%, \mathrm{v} / \mathrm{v}$ ), had no effect on basal or LH-stimulated progesterone synthesis. There was no effect of cytochalasin B or LH, alone or in combination, on the portion of progesterone found in the incubation medium (i.e. secretion) (Table 3 ). The addition of serum to the incubation medium increased the fraction of progesterone secreted into the medium by $15-21 \%$. This increase was maintained in the presence of $\mathrm{LH}$, cytochalasin $\mathrm{B}$, or $\mathrm{LH}+$ cytochalasin B.

Table 2. Effect of cytochalasin B on LH-stimulated progesterone synthesis of bovine luteal tissue in vitro

\begin{tabular}{lcc}
\hline & \multicolumn{2}{l}{ Progesterone synthesis $(\mu \mathrm{g} / \mathrm{g} / 2 \mathrm{~h})$} \\
\cline { 2 - 3 } \multicolumn{1}{c}{ Addition to medium } & No LH & With LH $(1 \mu \mathrm{g} / \mathrm{ml})$ \\
\hline None & $85 \cdot 1 \pm 4 \cdot 2$ & $132 \cdot 1 \pm 12 \cdot 3$ \\
Cytochalasin B $(1 \mu \mathrm{g} / \mathrm{ml})$ & $45 \cdot 3 \pm 9 \cdot 5^{*}$ & $54 \cdot 1 \pm 10 \cdot 2 \dagger$ \\
\hline
\end{tabular}

Values are mean + s.e.m.

Compared with control value; ${ }^{*} P<0.01(n=7) ; \dagger P<0.01(n=5)$.

Table 3. Effect of cytochalasin B on LH-stimulated progesterone secretion by bovine luteal tissue in vitro in the presence and absence of serum

\begin{tabular}{lcc}
\hline & \multicolumn{2}{c}{$\begin{array}{c}\text { Fraction of progesterone secreted into the } \\
\text { incubation medium (\%) }\end{array}$} \\
\cline { 2 - 3 } Addition to medium & No serum & With serum $(10 \%)$ \\
\hline None & $33 \cdot 5 \pm 1 \cdot 7$ & $54 \cdot 4 \pm 2 \cdot 4^{*}$ \\
LH $(1 \mu \mathrm{g} / \mathrm{ml})$ & $33 \cdot 4 \pm 1 \cdot 8$ & $51 \cdot 9 \pm 3 \cdot 2^{*}$ \\
Cytochalasin B $(1 \mu \mathrm{g} / \mathrm{ml})$ & $34 \cdot 1 \pm 3 \cdot 1$ & $52 \cdot 0 \pm 2 \cdot 1^{*}$ \\
Cytochalasin B $+\mathrm{LH}$ & $35 \cdot 8 \pm 1 \cdot 9$ & $50 \cdot 0 \pm 2 \cdot 6^{*}$ \\
\hline
\end{tabular}

Values are mean \pm s.e.m. after a $2-h$ incubation.

* $P<0.001$ compared to non-serum treatments $(n=7)$. 
Neither colchicine nor vinblastine significantly altered progesterone production in the presence or absence of LH (Table 4). In addition, neither agent was able to alter the fraction of progesterone secreted into the incubation medium (Table 5). Although serum again induced a greater secretion of progesterone into the incubation medium, neither colchicine nor vinblastine altered this effect of the serum.

Table 4. Effect of colchicine and vinblastine on LH-stimulated progesterone synthesis by bovine luteal tissue in vitro

\begin{tabular}{lcc}
\hline & \multicolumn{2}{c}{ Progesterone synthesis $(\mu \mathrm{g} / \mathrm{g} / 2 \mathrm{~h})$} \\
\cline { 2 - 3 } Addition to medium & No LH & With LH $(1 \mu \mathrm{g} / \mathrm{ml})$ \\
\hline None & $67.7 \pm 4.9(9)$ & $129.6 \pm 5.7(9)$ \\
Colchicine $(2 \mu \mathrm{g} / \mathrm{ml})$ & $74.1 \pm 7.2(9)$ & $110.4 \pm 12.9(9)$ \\
Vinblastine $(1 \mu \mathrm{g} / \mathrm{ml})$ & $63.4 \pm 9.5(4)$ & $97.2 \pm 21.5(4)$ \\
\hline
\end{tabular}

Values are mean \pm s.e.m. for the no. of CL incubations indicated in parentheses.

Table 5. Effect of colchicine and vinblastine on LH-stimulated progesterone secretion by bovine luteal tissue in vitro in the presence and absence of serum

\begin{tabular}{lcc}
\hline & \multicolumn{2}{c}{$\begin{array}{c}\text { Fraction of progesterone secreted into the } \\
\text { incubation medium (\%) }\end{array}$} \\
\cline { 2 - 3 } Addition to medium & No serum & With serum (10\%) \\
\hline None & $33.7 \pm 3 \cdot 7$ & $55 \cdot 3 \pm 2.9^{*}$ \\
LH $(1 \mu \mathrm{g} / \mathrm{ml})$ & $33.2 \pm 1.2$ & $52 \cdot 4 \pm 2 \cdot 6^{*}$ \\
Colchicine $(2 \mu \mathrm{g} / \mathrm{ml})$ & $37.9 \pm 2 \cdot 1$ & $54 \cdot 7 \pm 2 \cdot 0^{*}$ \\
Colchicine $+\mathrm{LH}$ & $32.9 \pm 2 \cdot 8$ & $59 \cdot 2 \pm 2 \cdot 1^{*}$ \\
Vinblastine $(1 \mu \mathrm{g} / \mathrm{ml})$ & $35.4 \pm 1.0$ & $50.7 \pm 0.5^{*}$ \\
Vinblastine $+\mathrm{LH}$ & $35.9 \pm 1.2$ & $48.6 \pm 0.9^{*}$ \\
\hline
\end{tabular}

Values are mean \pm s.e.m. after a 2 -h incubation.

$* P<0.001$ compared to non-serum treatments $(n=4)$.

\section{Discussion}

This study examined the role of two components of the cytoskeleton, microtubules and microfilaments, in LH-stimulated progesterone synthesis and secretion by bovine luteal tissue. Exposure of the luteal tissue to cytochalasin B inhibited basal and $\mathrm{LH}$-stimulated progesterone production, but had no effect on the ability of the luteal cells to secrete progesterone into the incubation medium. These results suggest that microfilaments may be involved in modulating progesterone production, but not in secretion of progesterone. Although the effects of cytochalasin B on bovine luteal cells have not previously been reported, studies of ovine (Silavin et al., 1980) and rat (Azhar \& Menon, 1981) luteal cells support our observation that cytochalasin B decreases LH-induced progesterone production. However, Cortese \& Wolff (1978) reported that in mouse adrenal (Y-1) tumour cells cytochalasin B stimulated steroidogenesis and that the steroidogenic effect of the cytochalasin B was exhibited in the presence of serum, thus suggesting that the cytochalasin exerted its effect by increasing the availability of cholesterol contained in the high-density lipoprotein of the serum. The results of the present study, as well as those of Azhar \& Menon (1981) and Silavin et al. (1980), show that 
the inhibitory effect of cytochalasin B on steroid production is not altered in the presence of serum.

Our study also shows that the presence of serum results in a significant increase in the proportion of progesterone found in the incubation medium. This increased secretion caused by the serum is independent of $\mathrm{LH}$ (unpublished results). Cytochalasin B was unable to prevent this increased secretion caused by the serum in either control or LH-stimulated tissue. Thus, although cytochalasin B depresses progesterone synthesis (and therefore the total amount of progesterone in the incubation flask), it has no effect on the secretion of progesterone into the incubation medium. This is also the case in the presence of $\mathrm{LH}$ and/or serum.

The mechanism by which cytochalasin B depresses progesterone synthesis is unknown. Azhar \& Menon (1981) have shown that it is not the result of inhibiting transport of glucose, and is not due to a non-specific toxic effect when employed at the concentrations used in this study. Silavin et al. (1980) propose that cytochalasin B works at a point before the conversion of cholesterol to pregnenolone, but Murono, Lin, Osterman \& Nankin (1980) have reported that in the interstitial (Leydig) cell of the testis, it blocks the conversion of pregnenolone to testosterone in the smooth endoplasmic reticulum. Murono et al. (1980) also suggest that cytochalasin B prevents the LH-induced generation of cyclic AMP. This view is supported by Zor, Strulovici \& Lindner (1978) in cultured Graafian follicles, but is contradicted by Silavin et al. (1980) and Azhar \& Menon (1981).

Therefore, although there is a lack of agreement on the mechanism of action of cytochalasin B, it appears that there is general support for the results of the present study on the cytochalasin B-induced inhibition of LH-stimulated progesterone production. There is not such general agreement, however, among the published reports concerning the effects of the antimicrotubular agents, such as colchicine and vinblastine. The present study shows that neither colchicine nor vinblastine was able to alter the synthesis or secretion of basal or LH-stimulated bovine luteal progesterone. Furthermore, the drugs were unable to prevent the increased secretion of progesterone induced by serum. Microtubules therefore appear to play no direct role in either synthesis or secretion of luteal progesterone. These results are consistent with those of Zor et al. (1978), who showed that colchicine had no effect on the ability of LH to stimulate cyclic AMP in cultured rat Graafian follicles, and those of Azhar \& Menon (1981), who showed that colchicine failed to affect either synthesis or release of progesterone in gonadotrophin-stimulated rat luteal cells. In contrast, in-vivo injection of colchicine into ewes has been reported to cause a decrease in blood progesterone concentration with a concomitant increase in luteal intracellular progesterone content (Gemmell \& Stacy, 1977). Sawyer et al. (1979) used an ovine luteal tissue slice preparation and reported that although colchicine had no effect on basal progesterone secretion, it caused a significant decrease in LH-stimulated progesterone secretion if added 30 min before the addition of the LH. Although colchicine was added $30 \mathrm{~min}$ before $\mathrm{LH}$ in the present study, Azhar \& Menon (1981) reported that preincubation of luteal cells with colchicine had no effect on subsequent gonadotrophin-stimulated progesterone production.

From these studies, we conclude that cytochalasin B inhibits basal and LH-stimulated progesterone production, but is unable to influence the secretion of progesterone from the luteal cell. In contrast, colchicine and vinblastine were unable to alter either synthesis or secretion of bovine luteal progesterone. Whether the inhibitory effect of cytochalasin B on steroidogenesis is a direct action of the drug or whether it is mediated by inhibition of microfilament function remains to be determined.

Scientific Contribution Number 1104 from the New Hampshire Agricultural Experiment Station. We thank Valerie Morrison for excellent technical assistance; Dr G. D. Niswender for the progesterone antiserum; and Dr A. E. Wilhelmi of the Hormone Distribution Program of the NIAMDD-NIH for the LH. This research was supported by the Northeastern Cooperative Regional Project NE-72. 


\section{References}

Azhar, S. \& Menon, K.M.J. (1981) Receptor-mediated gonadotropin action in the ovary. Action of cytoskeletal element-disrupting agents on gonadotropin-induced steroidogenesis in rat luteal cells. Biochem. J. 194, 19-27.

Bassett, J.R. \& Pollard, I. (1980) The involvement of coated vesicles in the secretion of corticosterone by the zona fasiculata of the rat adrenal cortex. Tissue \& Cell 12, 101-115.

Catt, K.J. \& Dufau, M.L. (1976) Basic concepts of the mechanism of action of peptide hormones. Biol. Reprod. 14, 1-15.

Christensen, A.K. \& Gillim, S.M. (1969) The correlation of the fine structure and function in steroid-secreting cells, with emphasis on those of the gonads. In The Gonads, pp. 415-488. Ed. K. W. Kerns. North Holland, Amsterdam.

Condon, W.A. \& Black, D.L. (1976) Catecholamineinduced stimulation of progesterone by the bovine corpus luteum in vitro. Biol. Reprod. 15, 573-578.

Cortese, F. \& Wolff, J. (1978) Cytochalasin-stimulated steroidogenesis from high density lipoproteins. J. Cell Biol. 77, 507-516.

Gemmell, R.T. \& Stacy, B.D. (1977) Effects of colchicine on the ovine corpus luteum: role of microtubules in the secretion of progesterone. $J$. Reprod. Fert. 49, 115-117.

Gemmell, R.T., Stacy, B.D. \& Thorburn, G.D. (1974) Ultrastructural study of secretory granules in the corpus luteum of the sheep during the estrous cycle. Biol. Reprod. 11, 447-462.

Gibori, G., Antczak, E. \& Rothchild, I. (1977) The role of estrogen in the regulation of luteal progesterone secretion in the rat after day 12 of pregnancy. Endocrinology 100, 1483-1495.
Lacy, P.E. (1975) Endocrine secretory mechanisms. Am. J. Pathol. 79, 170-175.

Marsh, J.M. (1976) The role of cyclic AMP in gonadal steroidogenesis. Biol. Reprod. 14, 30-53.

Means, A.R. \& Dedman, J.R. (1980) Calmodulin in endocrine cells and its multiple roles in hormone action. Molec. cell. Endocr. 19, 215-227.

Murono, E.P., Lin, T., Osterman, J. \& Nankin, H.R. (1980) The effects of cytochalasin B on testosterone synthesis by interstitial cells of rat testis. Biochim. Biophys. Acta 633, 228-236.

Parry, D.M., Willcox, D.L. \& Thorburn, G.D. (1980) Ultrastructural and cytochemical study of the bovine corpus luteum. J. Reprod. Fert. 60, 349-357.

Quirk, S.J., Willcox, D.L., Parry, D.M. \& Thorburn, G.D. (1979) Subcellular location of progesterone in the bovine corpus luteum: a biochemical, morphological and cytochemical investigation. Biol. Reprod. 20, 1133-1145.

Savard, K. (1973) The biochemistry of the corpus luteum. Biol. Reprod. 8, 183-202.

Sawyer, H.R., Abel, J.H., Jr, McClellan, M.C., Schmitz, M. \& Niswender, G.D. (1979) Secretory granules and progesterone secretion by ovine corpora lutea in vitro. Endocrinology 104, 476-486.

Silavin, S.L., Moss, G.E. \& Niswender, G.D. (1980) Regulation of steroidogenesis in the ovine corpus luteum. Steroids 36, 229-241.

Zor, U., Strulovici, B. \& Lindner, H.R. (1978) Implication of microtubules and microfilaments in the response of the ovarian adenylate cyclase-cyclic AMP system to gonadotropin and prostaglandin $E_{2}$. Biochem. Biophys. Res. Commun. 80, 983-992.

Received 24 June 1981 